\title{
Modelling Genesis of Intracratonic Chains Related to Tectonics Inheritance. Case Study from Gafsa Basin (Southern Central Tunisia)
}

\author{
Mohamed Sadok Bensalem, Mohamed Ghanmi \& Fouad Zargouni \\ University of Sciences of Tunis, Tunis El Manar \\ Universities Campus 2092, Tunis \\ E-mail: bensalemsadk@gmail.com
}

\begin{abstract}
Tectonic inheritance is a concept proved by the importance of tectonic phase's variation during time. It is related to reactivation in compression of old normal faults. In our study we will focus on Gafsa basin that is an example of intracratonic chain. The tectonic data confirm that it is affected by several tectonics phases; they began with Triassic distension continuing to Cretaceous and followed by resumption in compression according to NW-SE direction during alpine phase. Structural reliefs observed in Gafsa Basin are interpreted according to the "fault related fold" theory, by using the model of 'fault propagation fold'. The applications of this model will show a decollement level within the Triassic series. In addition, an important deformation will be identified while approaching to faults. The data elaborate from field confirm the role of these faults in the interpretation of tectonic heritage and development of intracratonic chains in Gafsa Basin.
\end{abstract}

Keywords: Tectonic inheritance, Intracratonics chains, Fault related fold, Fault propagation fold, Decollement level

\section{Introduction}

The tectonic inheritance was the object of several studies showing the important polyphase deformation of the tectonic activities during the time. The history of the reconstruction of continental platforms in globe is related to more than one tectonic activity; it begins with the extension given by the decomposition of Pangea according to the great old normal faults. This period was followed by the dominance of compression and installation of large orogenic relief.

The problem is to model this tectonic inheritance and interpret the detached foreland structures always in Consideration with the influence of extensive heritage. For a better interpretation it is important to study the structures on the front of orogens, and more precisely on the level of vast fields of certain external zones.

In the external orogenic zones the interpretation of brittle deformations can be solved according to the notion of ramps that is developed by the theory of balanced cross section. The application of this model is verified only when the mode of deformation accompanying the movement on the ramp is checked Menard (1988).

Among these modes we can quote "fault bend folding" developed by (Dahlström 1970; Suppe 1983); hence the model of 'fault propagation fold', (Suppe and Mdwedeff 1984; Suppe 1985 and Jamisson 1987). In addition the model of listric faults and concentric folds Dahlströme $(1970,1990)$ and finally the composite mode of "chester", Chester (1990). In the application of these models it is necessary to check the geometry of the external zones of chains to a better interpretation of the suitable style of deformation. What summer proven by Mercier $(1990,1995)$.

The tectonic heritage resulted from the resumption in compression of old normal faults in external zones interpreted by the notion of 'faults related folding'. This concept is related to an important movement on the ramps. For better understanding of this idea we have to study intracratonic chains from the example of Gafsa Basin.

The Gafsa Basin forms the southern border of Tunisian Atlas. It is delimited from Saharan platform by the southern Atlasic front, which is spread out from Agadir in Marocco to the folded structure of the chotts chains over 2000 kilometres.

The activity of this front was the object of several studies as a paleogeographic limit between two fields; one tectonized formed by Atlasic chains and the other stable defined by Saharan platform (Figure 1). 
In Tunisia this front affected the southern Tunisian Atlas by the two faults of Gafsa and El Mich. The Gafsa basin is constituted with anticlines separated by tabular field. We notice that the major direction of these anticlines is E-W to NW-SE.

The genesis of structures in this area was interpreted by several authors, that Zargouni (1985) who considered us echelons folds that deep seated in craton structures. However, Outtani (1985) and Ahmadi (2006) proved that those folds are related to the emergence of major strike-slip fault or tear-fault affecting only the coverage, but will reactivate the inheritance structures (Figure 2).

The juxtaposition of the two largest chains in Gafsa Basin, that of Orbata and Bouhedma, form a tectonic corner named the 'Orbata-Bouhedma junction'

The aim of this contribution is to interpret different tectonics events affecting Cretaceous series in Orbata-Bouhedma junction and set up a model of their installation in order to prove the importance of reactivation in compression of old normal faults.

\section{Methodology}

This study is interested in determining the installation mode of the intracratonic chains in Gafsa Basin referring to the construction of balanced cross section. It was made by using several steps related to:

A stratigraphic study was carried out of different formation leveling in the sector. Such a thickness or facies variation are related to a synsedimentary tectonic activity

A fine cartography of the sector, demonstrates the different faults activity during tectonics phases, basing on development of geological cross section.

For this work we used the numerical software Rampe E.M. (Mercier, 1990, 1994), the modeling of geological structures is carried out by balancing cross section with always preserving ground data.

Several tests are done in order to approach the suitable model. The results obtained by modeling allow us to interpret; decollement level, the thickness crossed by the ramp and the displacement carried out during deformation.

The last stage is to interpret the results obtained by modeling and to compare them with the petroleum drilling in the studied zones.

\section{Result}

\subsection{Cartographic data}

Our geological map elaborated shows the outcroping of Cretaceous series cut out by faults in different directions. We distinguish faults of N110 to N120 direction, other of direction N150 to N160 and East-West direction (Figure 3).

The morphology of Orbata-Bouhedma junction is related to an important variation of direction from NW-SE in the western sector, to E-W in the east. This variation was interpreted in Gafsa Basin by Zargouni (1985) with an intervention of dextral strike-slip fault related to major faults with N120 E ${ }^{\circ}$ direction, whereas Boukadi (1984) proposed the assumption of torsion around the vertical axes. Zouari (1990) considered the importance of the extensive structural heritage associated later to folding of structures with curved axes. Finally, Ibouh et al (1993) combined the activity of the dextral strike-slipe faults with the overlapping of Fault in Jbal Bouhedma.

In order to have an interpretation of genesis of structures it is important to begin with studying the data observed in field presented in form of stratigraphics and structural data.

\subsection{Stratigraphic data and synsedimentary activity}

All formations outcropping in the sector are defined on the following stratigraphic columns (Figure 4).

The detailed studies of these formations show a significant variation of thickness and facies from one area to another.

Firstly the examination of dolomites of Meloussi formation shows slits, clogged later by calcites. These slits with $\mathrm{NW-SE}$ major direction resulted from an extensive tectonic activity with the same direction of lengthening axis than that of slits

The Bouhedma Formation, aged higher Hauterivien lower Barrémien, presents a great variation of facies. In Eastern termination of Jbal Orbata at the level of Jbal Taghrout, this formation is defined by sequences of argilloarenaceous and other argillodolomitic in addition to very fine sand and rare gypsum level. While approaching to Jbal Bouhedma, to the Eastern termination of the Jbal BouMiza, we distinguish predominance of argilloarenaceous silty sequences.

This formation presents at the level of Jbal Taghrout some figures of 'slumps' with intercalation of carbonated nodules indicating slope's instability. That confirms an extensive activity at the origin of the creation of a shallow and swing the northern side of Eastern termination of Orbata chain (Figure5). 
The study of slickenside affecting the Barremo-Hauterivian series proved an extensive mode of deformation, with NW-SE direction of lengthening axis; it is a normal fault that permits the pinching out of series and creation of horst and grabens.

The Orbata Formation, for Aptian aged, corresponds to dolomitic cornices represents at the level of Jbal Timidwin in form of staircase shape. This structure is delimited by normal faults of NE-SW direction; thus indicating an extensive activity.

Thickness variation is also observed in other formation from one area to another. For example, going from Jbal At Tahir in the North-East sector to Jbal Sgoufta, the stratigraphic sequences given by the formation of Sidi Aïch, Orbata and Zebbag show a thickness reduction and even gap of Aleg and Abiod formations. This thickness reduction is related to the synsedimentary activity faults FS and FM.

In the area of Bou Blal the thickness of Aleg Formation can reach 500 metres, whereas in the area of Migli their total thickness does not exceed 10 metres. It is represented primarily by breaches of dissolution and conglomerates carbonated indicating significant tectonics synsedimentary during this period.

Lithostratigraphic correlation to level of Orbata-Bouhedma junction shows a thickness variation of certain formations and gap of others related to the tectonics activity of faults such as the Sgoufta Fault FS and that of El Mich FM (Figure $6)$.

This thinning of series was already proven by lithostratigraphic correlation carried out on both sides of faults quoted. Slickenside Data of FS (N160, 70NE) prove an extensive activity. The lengthening axis is NE-SW direction.

To North-East of our sector we notice a direct contact between carbonates of higher Zebbag formation with limestones dissociated and dismantled of Aleg formation. These limestones dissociated from dissolution of breaches observed in Khanguit elbhima area result from creeps of anhydrites which surmount limestone at the base of Aleg Formation. These breaches constitute an argument of bottom instability in the basin related to a tectonic activity during Turonian and Coniacian. Moreover, the Aleg Formation shows a pinching out of series that prove the activity of the FS fault and even total gap to the East of FM fault; it is an extensive activity (Figure 7)

These sedimentary and structural data confirms the extensive activity affecting Gafsa Basin during Early Cretaceous. It is an activity that confirmed by several authors (Zargouni, 1985). It continues to express during Late Cretaceous affecting the dolomitic cornices of Orbata Formation (Aptian age), Zebbag formation (Albian to Turonian age) and it continues even during Coniacian (Indicated by dissolution's breaches of Aleg Formation).

\subsection{Structural data}

The first cross section studied affects the east extremity of our sector for NW-SE direction. It shows an anticline structure cut out by synsedimentary faults (Fig 8).

This cross section determined by an anticline of N30 axis direction, the series have almost identical dip on two flank (about $45^{\circ}$ ), whereas the layers in the heart are rather rectified with an acute hinge. (Figure 9).

The heart of the anticline is affected by a fault of N30 direction; it permitted the swing of NW side and the rising of southern side. This activity explains the thickness reduction of series. More to SW this fault was already studied by Zouari et al. (1990) at the level of Jbal Zaicha which confirmed their normal activity without excluding its reactivation.

The direction of anticline axis proves that the genesis of this structure is related to a shortening of NW-SE direction, it is the same direction of lengthening axis during Cretaceous.

The faults affecting Jbal ad Darin (N40 direction) confirms an extensive activity during lower Cretaceous. This activity continues to express even during deposits of Zebbag Formation (Upper Cretaceous). Faults will be taken again later by a compressive mode at the origin of their reactivation in sinisterly strick-slip-fault. This Compression is of shortening axis NNW-SSE direction; that is the direction of major shortening alpine on the scale of Tunisia. It is a shortening that also argued by sigmoid slits of direction N140 observed at the level of Jbal Bou Miza.

The second cross section is carried out in Jbal Sgoufta to NW and Jbal TazTigarit to SE affecting the solid mass of the Jbal Bou Miza. It shows an anticline with heart formed by a tectonic thickening structure.

The normal activity of Sgoufta Fault assigning the series of Sidi Aich to Zebbag Formation, presents a throw about 20 meters.

This cross-section was raised in a corner delimited on both sides by two faults of FS and FM. Respectively to the East and the west. These two faults prove an extensive activity during Cretaceous (marked by the beveling and even gap of series going from Bouhedma Formation until Abiod Formation), thereafter they will be reactivate by a compressive phase. It is the Atlasic compression of Tortonian age, at the origin of resumption of these two faults in dextral strik-slip-fault. The reactivation of this fault in dextral strik-slip-fault proves well that the general direction of shortening axis is NW-SE to submeridian. 
This corner is delimited by the two faults FS and FM; their reactivation is at the origin of an important deformation expressed by subverticalisation of layers at the level of Jbal Sgoufta and tectonic thickening structure. (Figure 10).

The Sgoufta massive is cut out by secondary synsedimentary fault of direction N150 to N170. Among these faults we can distinguish those which are inverted affecting the series of middle and higher Zebbag Formation. Those faults have a weak width and born on the prolongation of the old normal faults.

More to the east, and along the fault of El Mich, we find Jbal atTaghli; it is delimited by a tectonic lens. The folds in this zone have major direction N60, lay out in sigmoid form and separated one from other by secondary order faults. The genesis of these folds is related to shortening during compressive phases associated to tangential activity.

From west to east we can distinguish four folds defined by three anticlines separated by faults, whereas the only synclinal is observed in the east limit. The direction of those folds and their sigmoid form confirms that their genesis is related to a shortening of NW-SE direction; it is the direction of alpine compression, aged upper Tortonian. It is the most important in favor of the genesis of folds.

The tightening is continued to express, allowing the overlapping of anticlines, from west to east. Thus giving birth to imbricate structure in form of 'duplex' (Figure 11)

The important quantity of deformation in this tectonic corner explains the gap of synclinals between three anticlines, already quoted, and thus allows interpreting the overlapping of imbricate structures in the shape of 'duplex'.

The deformation accentuated is also proved by the subverticalisation of the faults which delimit the folds, whereas towards the east a synclinal structure constitutes the zone of forelimb.

We can interpret that the stratigraphic and structural data show that Gafsa basin is subject to more than one tectonic phase. During early Cretaceous reigns an extensive phase, of NW-SE direction, proven by the beveling of the series of formations Meloussi, Bouhedma and even Boudinar. This phase is shown by the normal activity of faults, and continues to express even during late Cretaceous.

The resumption in compression during the alpine phase is carried out according to a shortening of NW-SE direction (it's the same direction of lengthening); what permeated the genesis of the great Atlasic structures (Jbal Orbata and Jbal BouHedma). This compression continues to occur until actual with submeridian direction of shortening allowing the reactivation of the old normal faults even in inverted fault.

To leave the structural chart of studied sector (Figure 12) we notice that the deformation increases on both sides of fault. While going from the west to the east sector and approaching to El Mich fault, the structural reliefs show an important rising with individualization of tectonic thickening structures (towards the south of the J. Sgoufta and at the level of Jbal Sha'bita and Jbal Abd Allah).

More to north east, on the level of the Jbal at Tahgli, the fault of El Mich confirms its important role in the genesis of imbricate structures. The secondary faults as being breakable disunite the folds leading to the overlapping of anticlines; they are the tears faults

We can interpret that the genesis of structures is related to the reactivation of old normal faults during different compressive phases, hence the importance of tectonic inheritance concept. Any interpretation of installation mode of structures must take into consideration the role of old faults in their genesis, which will be better explained in the next part.

\section{Discussion and modelling}

\subsection{Discussion of results}

Stratgraphic and structural data studied in Orbata-BouHedma junction proved the activity of several tectonics phases from Trias until actual.

Since the Trias, central-Southern Tunisia was subject to an extensive mode expressed by normal faults. The most important ones are those of Gafsa and El Mich, which are at the origin of individualization of half grabens and grabens, also described in the seismic profiles affecting all the basin of Gafsa. Bedir et al. (2000).

This activity continued to express during the deposit of the early Cretaceous series which is proved by the pinching out of the layers. The examination of the slickenside affecting Boudinar and Bouhedma Formation that shows again a normal fault generally with the tilting of the north compartment. The origin of the creation of a Shallow that is explains the structuring of different slope's figures.

The extensive phase continues to express during late Cretaceous; indeed a thickness variation was already observed in Orbata and Zebbag Formation, which confirms that this extensive activity persists at the base of late Cretaceous.

More to Jbal At Tahir we notice an angular discordance of Abiod formation series with dolomites of Zebbag formation accompanied by an important pinching out of Aleg formation series (described by brecia's dissolution). 
It is an extensive phase during the deposit of Aleg Formation, which presents the continuity of extensive activity already quoted, taken again thereafter by a compano-maastrichtian compression. This late compression is of local order; it is of E-W direction, also described in Gafsa Basin. In our sector it is related to the blockage of the two massive of Orbata and BouHedma at the level of El Mich Fault

The western extremity of the sector shows an anticline with NE-SW direction, it is the Eastern termination of the Orbata chain formed by two symmetrical flanks. More approaching to Sgoufta and El Mich Faults, we notice an increase of deformation with individualization of tectonic thickening structure in the Jbal BouMiza termination. This structure is also observed in the southern sector in Jbal Sha'bita and Jbal Abd Allah. These two anticlines are wedged and delimited by faults without syncline. The compression associated to the reactivation of faults separated by anticline was permitted the sinking of synclines and outcroping only anticlines wedged at the level of faults.

Moreover, this structure is observed to Jbal atTaghli, it is imbricates anticlines delimited by faults without synclines. This structure resulted from an important deformation which affected this tectonic corner. It is related to reactivation of El Mich Fault during different phases of compression from Neogene until actual.

In fact, the genesis of these folds, of major direction N60, result from the alpine compression of shortening direction NW-SE. these folds are cut out by the ramifications of El Mich Fault.

More the compression increases (Villafranchian phase) than the rejuvenation of the faults is important, leading to the tilting of the synclines and the overlapping of the anticlines.

The corner of Jbal atTaghli presented in the form of tectonic lens delimited by two subparallel faults. Their combination activities were at the origin of wedging of the anticlines. It is the notion of tear fault.

The structural study of Orbata-BouHedma junction confirms some former works interested to close localities (Ahmadi 2006; Outtani1995). Indeed the geneses of the folds are related to tectonic inheritance and rejuvenation of old normal faults during different compressive phases that prove the concept of "fault related folding".

\subsection{Modeling}

In This part of contribution we present an interpretation by the modeling of stratigraphic and structural data related to different phases of deformations. This part of work was carried out by using numerical model developed by the software Ramps E.M. 1995.

This work started by interpreting the geometry of folds. Then balanced the cross-section obtained on the field, according to the suitable model. The general structural frame leads us based on the concept of ramps and balanced cross section.

The resumption in compression of these structures allows an inversion tectonic giving rise to folds, which are born on these old normal faults. During the genesis of these folds «fault related folding" they express on ramps. We distinguish particularly three types of "faults related fold" which are "fault bend fold", "fault propagation fold" and "chester". The difference between these models is related to the geometry of each one:

The most important factor to interpret the suitable model is the geometry of fold hinge. The cross section already elaborated on ground shows folds with hinge acute and subvertical layers (as watch Figure 9). This geometry is related particularly to the importance of fold's growth following an accommodating of slip on the spot. This geometry remembers the model of 'fault propagation fold'.

This model is also proved to NW termination of Jbal Bou Miza exactly in the north of wad Ed Dhribin, where the growth of fold was carried in a superficial context at the origin of raising structural relief. The phenomenon of erosion was activated is presented in conglomeratic deposits form at the base of structure in the frontal synclinal trough (Figure 13).

In this frontal trough bend we show a rounded pace very accentuated which indicated a less significant radius of curvature. It is explained by supplementary shearing related to recent compressive context superficial.

After determining the mode of deformation we propose to model the geological cross section already elaborated and then balanced by using numerical software called Rampe EM (Mercier, 1990-1995). The results obtained by this model allow us to interpret the altitude of lower dish, dip of downstream side (fore limb), dip of upstream side (back limb), crossed thickness and displacement (Figure 14).

After several tests of modeling we deduce that the decollement level is within triassic series, the ramps is blocked with the last carbonated level from Jurassic and their dip is about $38^{\circ}$ which explains the symmetrical plunging of the layers in the two sides of the anticline.

The adapted displacement is about $1.2 \mathrm{~km}$ related to a shortening of direction NW-SE from northern side. These parameters are in relation to the progression of the deformation at the origin of the modification of the mode to thrust 
propagation with shearing of the reversed limb. They allow important rising of the structural reliefs that will be eroded and deposited in the form of dismantlement products at the base of structure.

We should notice that this model is checked only with an important thickness of the Jurassic series which is 1000 meters. So this thickness was proved by the petroleum drilling carried out within the Gafsa basin. Indeed, towards the west in the area of Metlaoui a petroleum drilling GN presents a series thickness of Jurassic that do not exceed 500 meters, whereas while approaching to our sector other petroleum drilling KR and SO shows thickness which exceeds even 1500 meters.

This variation of series thickness of Jurassic is explained by the activity of Gafsa fault during Jurassic period (Figure 15).

The second cross section to be modeled is delimited by the two faults of Sgoufta and El Mich. It is also shows an anticline structure with a geometry which confirms the model of "Fault propagation fold" (acute hinge with rectified layers).

The balancing of cross section, by using the same software Rampe EM (Mercier, 1990, 1995), permeated us to adopt the model proposed on Figure 16.

This model shows again a decollement level in the Triassic series with a ramp which reaches the dolomitic levels of the base of Bouhedma Formation. We should state that in this model the displacement is more important than that observed in the preceding cross-section which confirms more deformation. This deformation is proved by the structural geometry forms of tectonic thickening.

The second cross section is delimited on both sides by the two faults FS and FM. So the rejuvenation in compression during the alpine phase was at the origin of an important blocking in the edge of these faults which explain even the subverticalization of layers at the level of Jbal Sgoufta.

The maximum of deformation is proven in the proposed model by an important displacement explained by the rising of structural reliefs. The maximum of deformation is also observed in Jbal atTaghli which show imbricates folds formed by overlapping anticlines (Figure 17).

In order to interpret the kinematics of Jbal atTaghli we notice that it is presented in the form of duplex structure with an important role of back-thrust activity. To the west of cross section, the migration of two anticlines is in the same direction of shortening, from NW to SE. However, the third fold presents a dipping of its axis in the opposite direction. This back-thrust is branched in a shallow decollement at a higher level. The genesis of structures is related to antithetic activity of fault in edge of major fault (fault El Mich).

\section{Conclusion}

The Orbata-BouHedma junction is subject to more than one tectonic phase which continues to express until actual. The synsedimentary tectonics analysis confirms that this sector is subject to an extensive activity from the lower Cretaceous. This distension that begins from Trias is responsible for the opening of the Atlantic Ocean and individualization of the great normal faults such as El Mich Fault. Thereafter an alpine Cenozoic compression permeated individualization of most chains in all Gafsa Basin. Another compressive activity other that alpine phase observed in our sector which are local and related to the combined activity of faults (compano-maastrichtian compression).

The Gafsa Basin is presented as a typical example of genesis of intracratonic chain. The developments of these chains are related to the resumption in compression of the old normal faults, according to the fault related folding mode. To understand the mode of installation of these structures we propose a geometrical modeling of 'forwards' which is based on the balancing of the geological Cross section. This method allows us to conserve the rough geological data of ground and interpret their geometry.

The rejuvenation in compression with the same direction axis of lengthening during alpine phase is at the origin of the development of the structures in old normal faults, proving the concept of 'fault related folding'. The proposed model of 'fault propagation fold' confirms the ground data already elaborated. It was checked by the petroleum drilling, soon a geophysical study on the same area can confirm the results obtained and verified the role of the tectonic heritage in the genesis of structures, which continues to express until actual.

\section{Acknowledgements}

This work is produced within the framework of preparation of doctorate Thesis in the Faculty of Science Tunis El Manar which is supported by the Ministry for Scientific Research, Technology and Development of the Competences. The authors are thankful to Mercier Eric how participated in the discussions of the results.

\section{References}

Ahmadi, R., Mercier, E., Ouali, J., Mansy, J.L., Van-Vliet Lanoe, B., Launeau, P., and Rhekiss, F. (2006). The geomorphological hallmarks of hinges migration in fault related folds. A study case in southern tunisian atlas. Journal 
of Structural Geology, 28, 721-728.

Alsaffar, M. (1993). Geometry of fault-propagation folds: methods and application, Tectonophysics, 223, 363-380.

Bedir, M., Zitouni, L., Boukadi, N., Saadi, J., Alouani, R., Ben Timzal, F., Tlig, S., and Bobier, C. (2000). Rifting, halocinèse et structuration des bassins péri-téthysiens jurassiques et crétacé inférieur de subsurface du domaine atlasique central de la Tunisie (région de Gafsa-Sidi Ali Ben Aoun). African Geosciences Revue. 7, 289-306.

Bedir, M., Boukadi, N., Tlig, S., Ben Timzal, F., Zitouni, L., Alouani, R., Slimane, F., Bobier, C., and Zargouni, F. (2001). Subsurface Mesozoic Basins in the Central Atlas of Tunisia, tectonics sequence deposit distribution and hydrocarbon potential. A.A.P.G. Bull. 85, 885-907.

Bernal, A., and Hardy, S. (2002). Syn-tectonic sedimentation associated with three-dimensional fault-bend fold structures: a numerical approach, Journal of Structural Geology, 24, p 609-635.

Bouaziz, S., Barrier, E. Soussi, M. Turki, M. M. and Zouari, H. (2002). Tectonic evolution of the northern African margin in Tunisia from paleostress data and sedimentary record. Tectonophysics, 357, 227-253.

Boukadi, N. (1984). Structuration de l'Atlas de Tunisie. Signification géométrique et cinématique des noeuds et des zones d'interférences structurales au contact de grands couloirs tectoniques [Ph D thesis ] University. Tunis II, Tunisia, 249p.

Bracène, R., Patriat, M. Ellouz, N. and Gaulier, J-M. (2003) - Subsidence history in basins of northern Algeria. Sedimentary Geology 156, p. 213-239.

Burollet, P.F. (1956). Contribution à l'étude stratigraphique de la Tunisie centrale. [Ph D Thesis], Paris. Annale des Mines et Géologie, Tunis, $350 \mathrm{pp}$.

Chester, J.S., \& Chester F.M. (1990). Fault propagation fold above thrust with constant dip. Journal of Structural Geology 12, 903-910.

Creuzot, G., Mercier, E., Ouali, J. and Turki, M. M. (1992). Héritage distensif synsédimentaire et structuration chevauchante : apports de la modélisation du chevauchement alpin de Zaghouan (Atlas tunisien). Comptes. Rendues. Académie. Science. Paris, 314, Série II, 961-965.

Dahlström, C.D.A. (1970). Structural geology in the eastern margin of the canadien Rocky Mountain, Canadian Bulletin of Petroleum Geology 18, p 332-406.

Dahlström, C.D.A. (1990). Geometric constraints derived from the law of conservation of volume and applied to evolutionary models for detachment folding. American Association Petroleum Geology 74, p 336-344.

Delcaillau, B. (2001). Geomorphic response to growing fault-related folds: example from the foothills of central Taiwan. Geodynamica Acta, 14, 265-287.

Delcaillau, B., Carozza J. M. and Laville, E. (2006). Recent fold growth and drainage development: The Janauri and Chandigarh anticlines in the Siwalik foothills, northwest India. Geomorphology, 76, 241-256.

Frizon D.L.D., Saint Bezar, B. Bracene R. and Mercier E. (2000). The two main steps of the Atlas building and geodynamics of the western Mediterranean. Tectonics, 19, 740-761.

Guiton, M.L.E., Sassi, W., Leroy, Y.M., and Gauthier, B.D.M. (2003). Mechanical constraints on the chronology of fracture activation in folded Devonian sandstone of the western Moroccan Anti-Atlas. Journal of Structural Geology 25, 1317-1330.

Ibouh, H., and Zargouni, F. (1993). Tectonique cassante et ductile de la faille de Meïch (Tunisie méridionale). Revue. Faculté Scieces Semlalia (Marrakech), Maroc v 7, p 99-107.

Jauzein, A., and Perthuisot, V. (1981). Accidents de socle et plissement de couverture, une hypothèse pour la structure de la Tunisie autochtone. Actes du Premier Congrés National des Sciences de la Terre (Tunis), Tunisia, pp. 405-416.

Khéssibi, M. (1978). Etudes géologiques du secteur de Maknassy-Mezzouna et du Djebel Kbar (Tunisie centrale). [Ph D thesis], University Claude Bernard, Lyon, France, 175p.

Mercier, E. (1992). Une évolution possible des chevauchements associés aux plis de propagation : le transport sur le plat (modélisation et exemple. Bulletin de la Société géologique de France, 163, 713-720.

Mercier, E. Rampe (EM). (1990-1995). softwar for modelling fault-related fold. Public Domain for Macintosh, version 1.5.2

Mitra, S. (1990). Fault propagation folds: geometry, kinematic evolution and hydrocarbon traps. Annales. Association Petroleum Geology Bulletin 74 p 921-945. 
M'Rabet, A. (1981). Stratigraphie, sédimentation et diagenèse carbonatée des séries du Crétacé inférieur de la Tunisie centrale. [Ph D thesis], University Paris sud, Centre d'Orsay, 540p.

Outtani, F., Addoum, B., Mercier, E., Frizon de Lamotte, D. and Andrieux, J. (1995). Geometry and kinematics of the South Atlas Front, Algeria and Tunisia. Tectonophysics 249, p 233-248.

Rafini, S. and Mercier E. (2002). Forward modelling of foreland progressive unconformities. Sedimentary Geology, 146, p 75-89.

Salvini, F., and Storti F. (2002). Three-dimensional architecture of growth strata associated to fault-bend, fault-propagation, and décollement anticlines in non-erosional environments. Sedimentary Geology, 146, p 57-73.

Suppe, J., (1983). Geometry and kinematics of fault-bend folding. American Journal of Science, 283, 684-721.

Whipple, K. X. and Tucker, G. E. (1999). Dynamics of the stream-power river incision model: Implication for height limits of mountain ranges, landscape response timescales, and research needs. Journal of Geophysical Research, 104, $17661-17674$.

Wilkerson M. S., Apotria T. and Farid T. (2002). Interpreting the geologic map expression of contrational fault-related fold terminations: lateral/oblique ramps versus displacement gradients. Journal of Structural Geology, 24, 593-607.

Zargouni, F. (1984). Style et chronologie des déformations des structures de l'Atlas méridional. Evolution récente de l'accident sud-atlasique. Comptes Rendues Académies des Sciences Paris 299, p 71-76.

Zargouni, F. (1985). Tectonique de l'Atlas méridional de Tunisie. Evolution géométrique et cinématique des structures en zones de cisaillement. [Ph D thesis] Sciences, University Louis Pasteur, Strasbourg, France, 296p.

Zargouni, F., Rabia, M.C. and Abbès, C. (1985). Rôle des couloirs de cisaillement de Gafsa et de Négrine-Tozeur dans la structuration du faisceau atlasique. Comptes Rendues Académies des Sciences Paris 306, p 831-834.

Zouari, H., Turki, M.M., and Delteil, J. (1990). Nouvelles données sur l'évolution tectonique de la chaîne de Gafsa. Bulletin Société Géologique France 8, p 621-628.

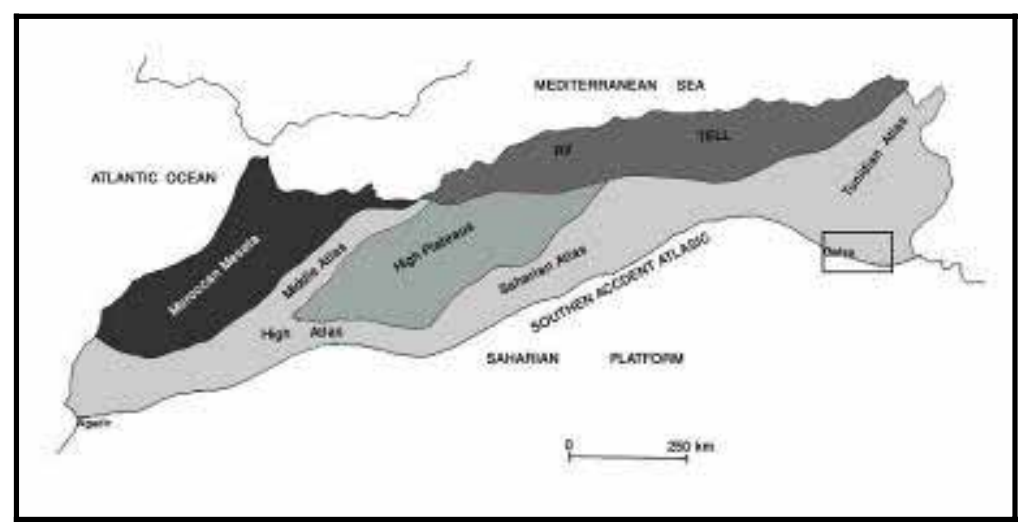

Figure 1. Presentation of different structures in the Atlasic chains of North African

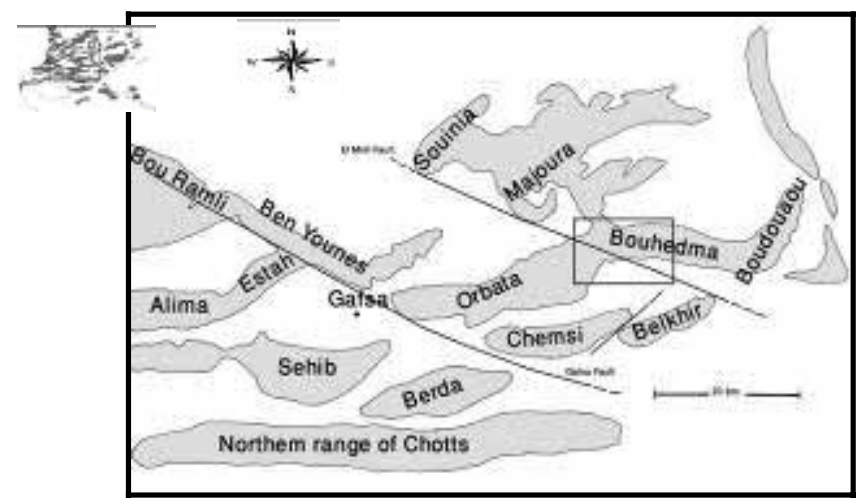

Figure 2. Localization Chart of studied sector in Gafsa Basin 


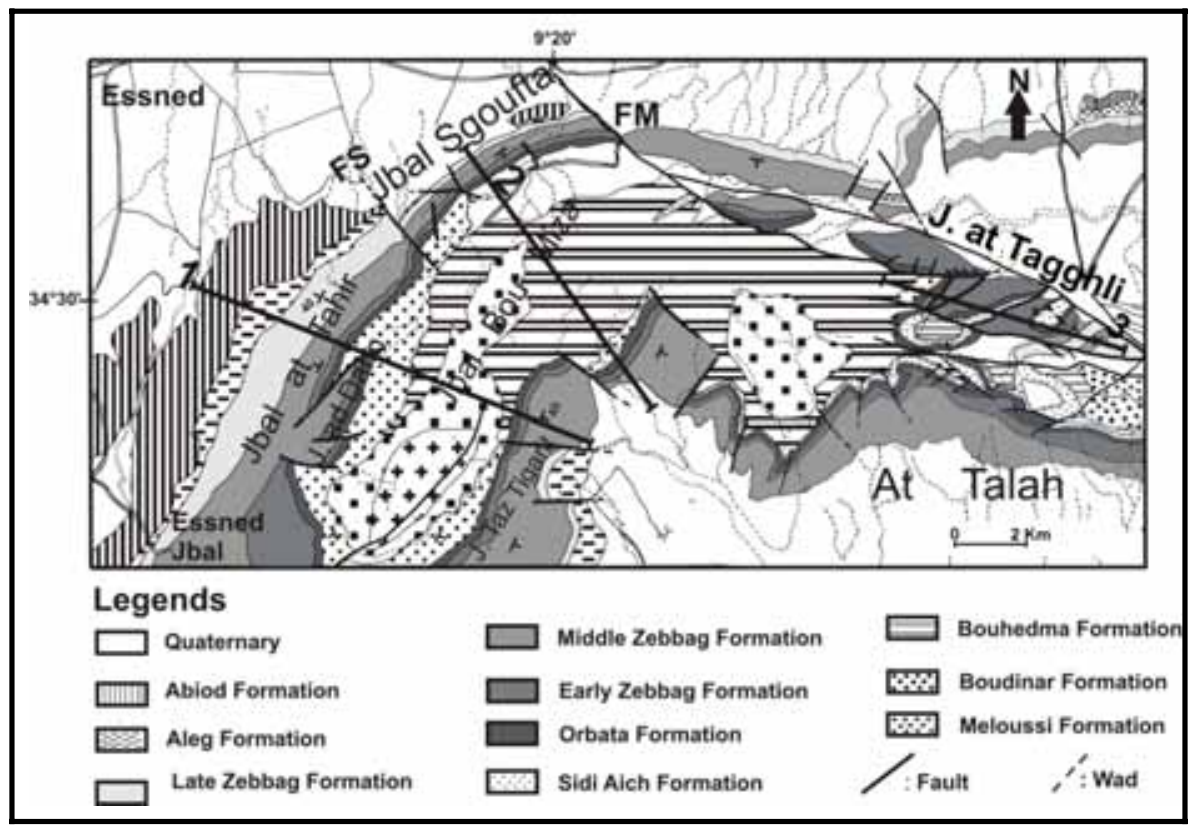

Figure 3. Geological map of studied sector showing the activity of different major faults

\begin{tabular}{|c|c|c|c|}
\hline Age & Formation & column & Lithology \\
\hline Albian & $\begin{array}{c}\text { Earty } \\
\text { Zebbag } \\
\end{array}$ & 3 & \\
\hline Aptian & Orbata & $\frac{1}{3 n 2^{2}}$ & $\begin{array}{l}\text { glternation marty } \\
\text { calcareous surmounted } \\
\text { by levets dotomitics. }\end{array}$ \\
\hline \multirow{2}{*}{ 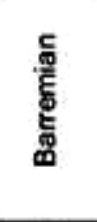 } & Sidi Aich & & $\begin{array}{l}\text { White Sands fine, } \\
\text { coarser towards the top }\end{array}$ \\
\hline & \multirow[t]{2}{*}{ Bouhedma } & 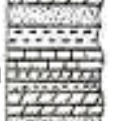 & $\begin{array}{l}\text { Mixed series with } \\
\text { allernation of variegaled } \\
\text { clays, the liking, the }\end{array}$ \\
\hline \multirow{2}{*}{ 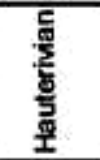 } & & 要高 & gyparm and carbonate. \\
\hline & Boudinar & $\left.\mid \begin{array}{cc}1 & 2 \\
3 & 2 \\
3 & 2\end{array}\right]$ & $\begin{array}{l}\text { Massive entity } \\
\text { quartzoes sand with } \\
\text { obliques stratification }\end{array}$ \\
\hline
\end{tabular}

\begin{tabular}{|c|c|c|c|}
\hline Age & Formation & column & Lithology \\
\hline Meastrichtian & \multirow{2}{*}{ Abiod } & \multirow{2}{*}{ 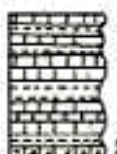 } & \multirow{2}{*}{$\begin{array}{l}\text { Pave carbonated } \\
\text { sumourted by } \\
\text { alternation merity } \\
\text { calcareous }\end{array}$} \\
\hline Campanian & & & \\
\hline Santonian & \multirow{3}{*}{ Aleg } & \multirow{3}{*}{ 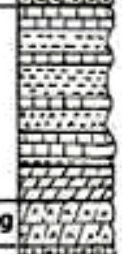 } & \multirow{2}{*}{$\begin{array}{l}\text { Levets carbonated } \\
\text { with rudists surmouted } \\
\text { by gipsum and } \\
\text { alternation of the } \\
\text { greenish marts and } \\
\text { lumechelic carbonote }\end{array}$} \\
\hline Coniacian & & & \\
\hline Turonian & & & $\begin{array}{l}\text { Massive dolomilic bar } \\
\text { with yelow petina }\end{array}$ \\
\hline Cenomanian & $\begin{array}{l}\text { Middle } \\
\text { Zebbeg }\end{array}$ & 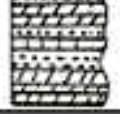 & $\begin{array}{l}\text { Alternation of dolomite } \\
\text { benches, clays and } \\
\text { lumpchelic benches } \\
\text { rich in Echinodermata. }\end{array}$ \\
\hline
\end{tabular}

Figure 4. Lithostratigraphic column describing different formations studied in the sector: series of the early Cretaceous are to the right and those of late Cretaceous are to the left.

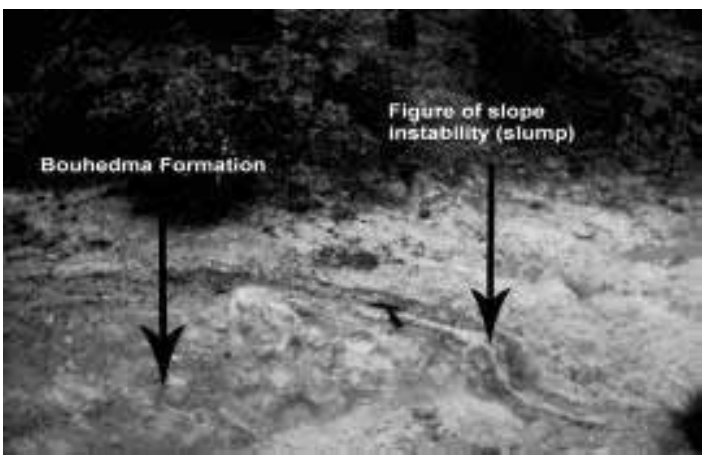

Figure 5. Slumps Figures affecting Bouhedma formation related to slope instability that indicate an extensive activity during early Cretaceous. 


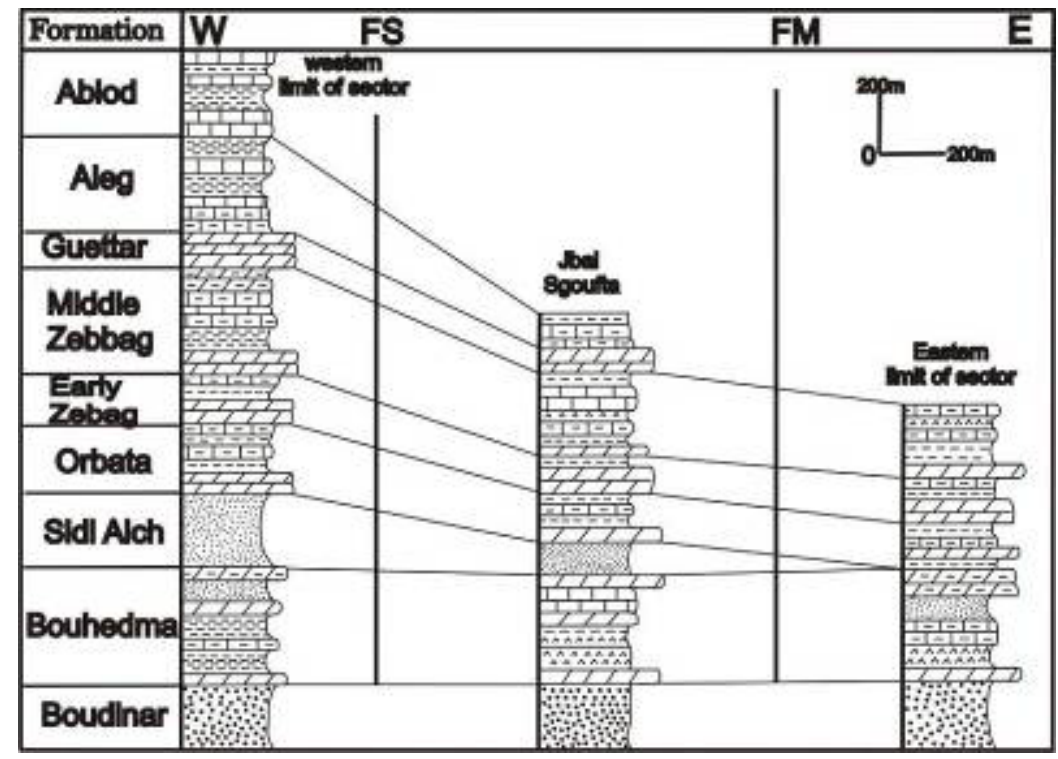

Figure 6. Lithostratigraphic Correlation of Cretaceous series on both sides of Sgoufta Fault FS and El Mich fault FM

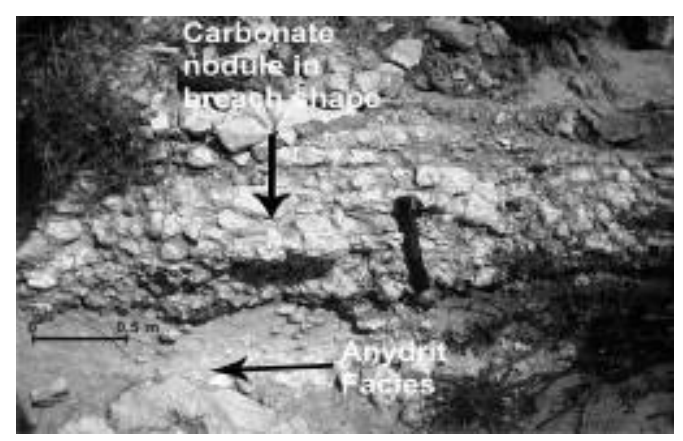

Figure 7. Dissolution's breccia of Aleg formation confirms the extensive activity during Coniacien age

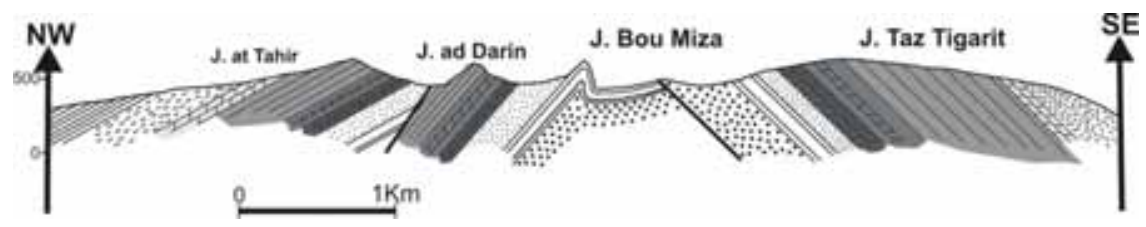

Figure 8. Cross section elaborated at the Eastern termination of Orbata mass showing a monocline structure affected by sinistral strike-slip fault (same legends of figures 3) 


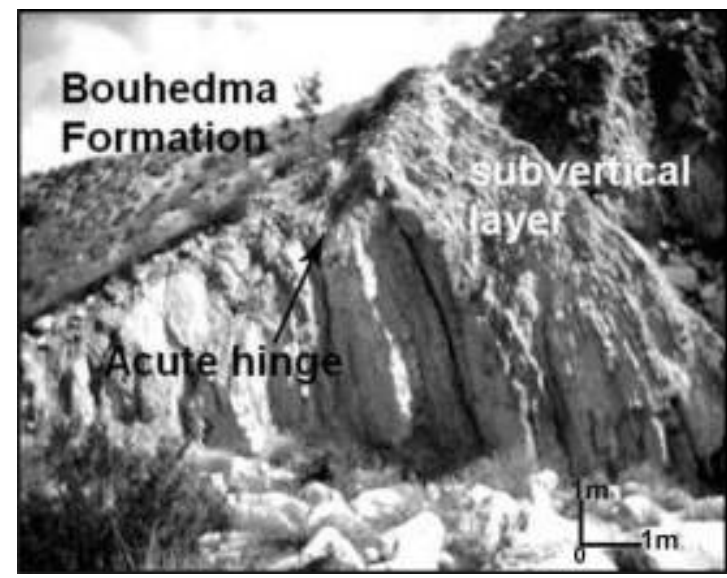

Figure 9. Geometry of fold presented by acute hinge and subvertical layer

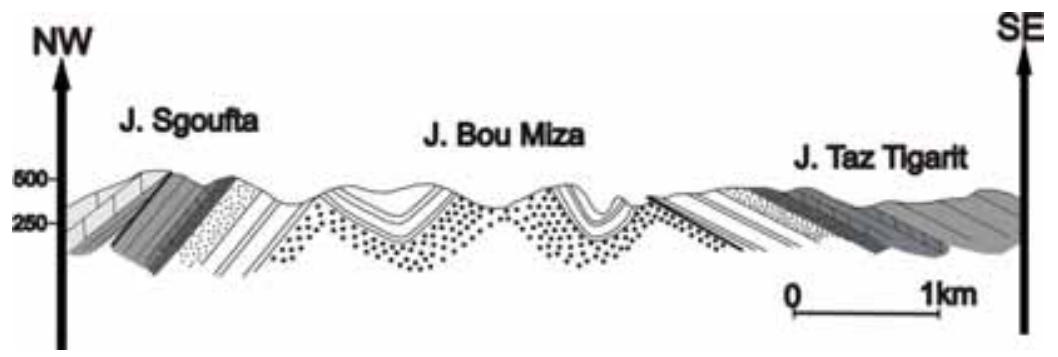

Figure 10. Geological cross section of Jbal Sgoufta proving an important tectonic deformation between the two faults of FS and FM

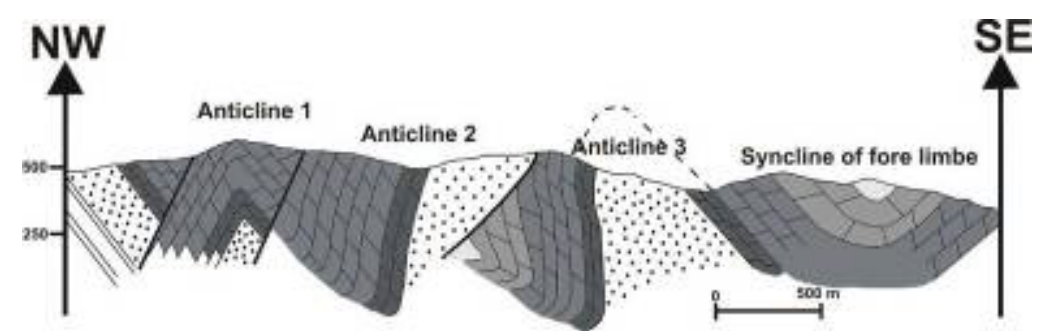

Figure 11. Cross section at the level of Jbal atTaghli showing the overlapping of the four folds separated by faults offered the form of "duplex" (same legends of figures 3) 


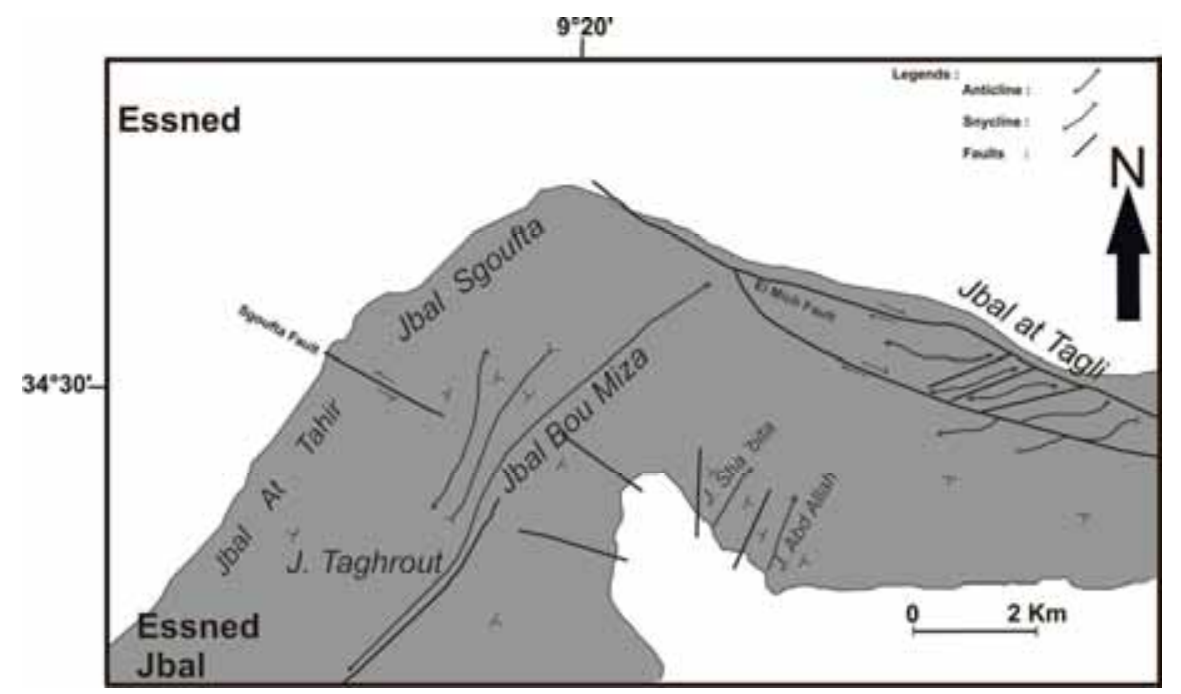

Figure 12. Structural chart of studied sector proving the important role of faults in the increase of deformation

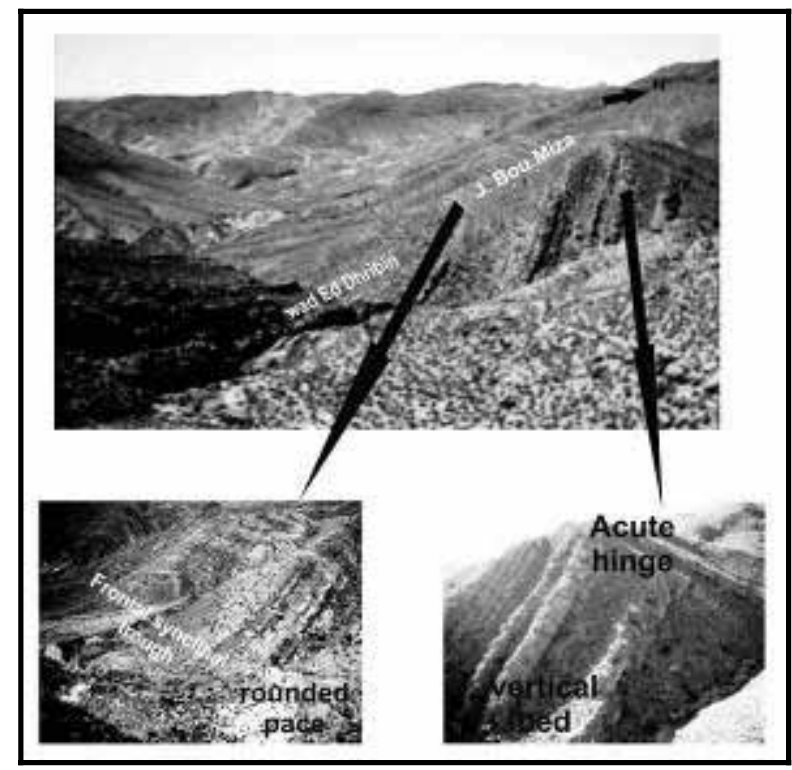

Figure 13. Morphology of the folds in form of acute hinges shape and rounded pace of the frontal syncline trough

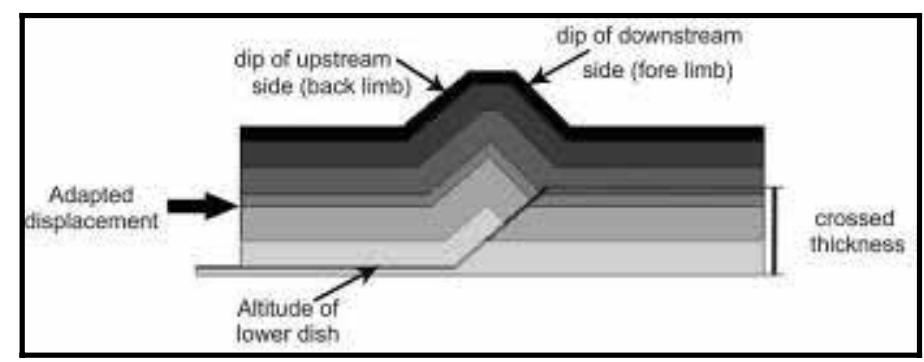

Figure 14. Different parameters interpreted in the application of model fault related fold 


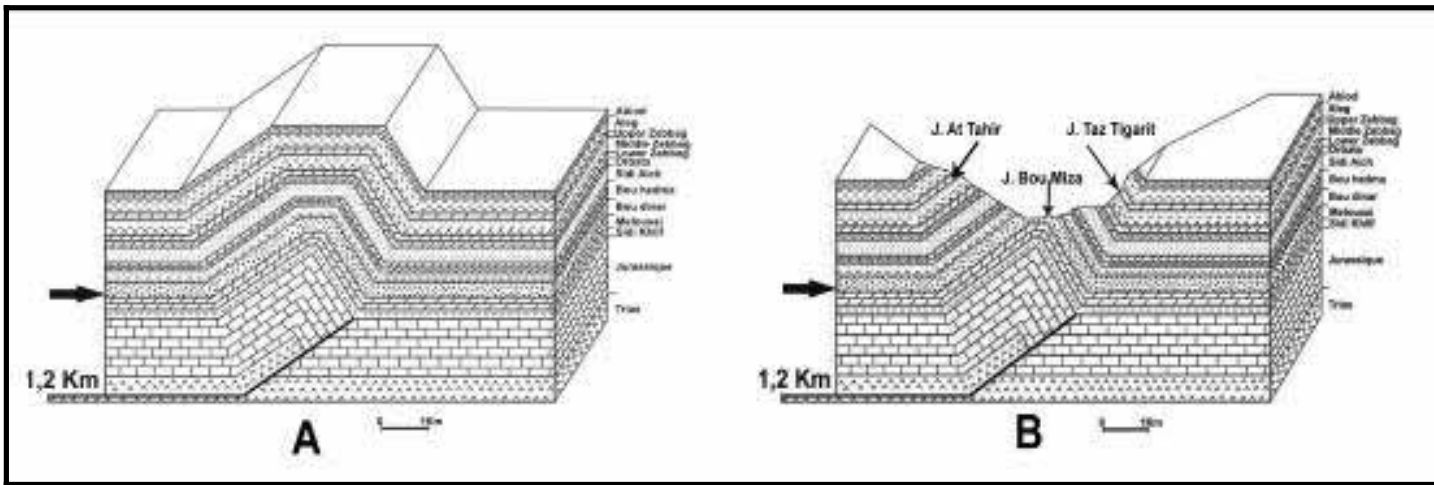

Figure 15. A: Result of modeling of cross section 1 in mode of fault propagation fold; B: Model of cross section 1 resulted after erosion.

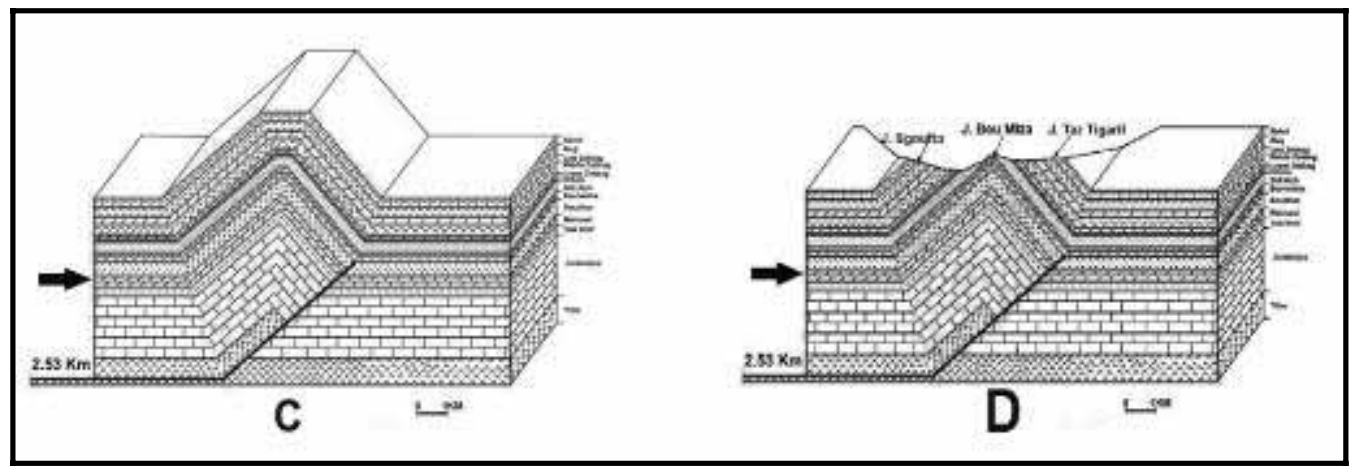

Figure 16. C: Result of modeling of cross section 2 in mode of fault propagation fold; D: model of cross-section 2 affected by erosion.

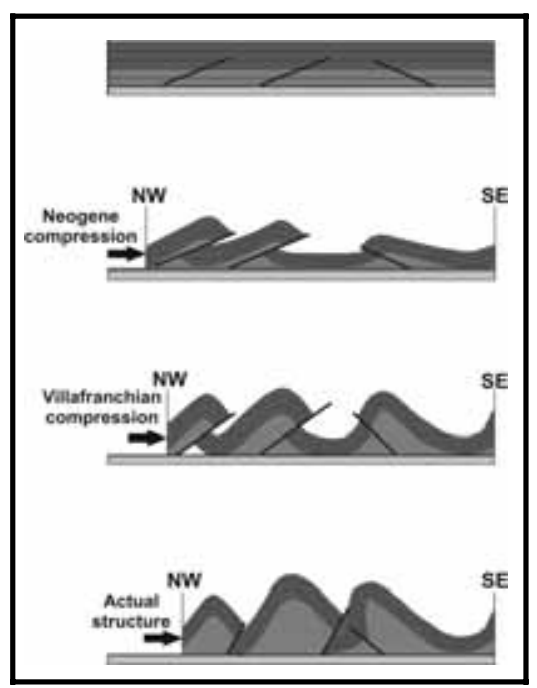

Figure 17. Kinematic and genesis of Jbal atTaghli in form of duplex structures resulted to reactivation of El Mich fault 